\title{
Antimicrobial Activity of Plants Collected from Serpentine Outcrops in Sri Lanka
}

\author{
Nishanta Rajakaruna, Cory S. Harris and G.H.N. Towers \\ Department of Botany, University of British Columbia, Vancouver, Canada
}

\begin{abstract}
Thirty-two plant species collected from serpentine (ultramafic) soils in Sri Lanka were screened for antimicrobial properties against three Gram-positive and two Gramnegative bacteria, a non-acid fast bacterium, and the yeast, Candida albicans. Methanol extracts of 29 species belonging to 12 families were active against at least one microorganism. Activity against the Gram-positive and non-acid fast bacteria was common, however, only two taxa, Lantana camara L. (Verbenaceae) and a species of Phyllanthus L. (Euphorbiaceae), were active against the Gram-negative bacterium Pseudomonas aeruginosa. None of the species was active against the other Gram-negative bacterium, Escherichia coli, or C. albicans. Photoactivity was observed from extracts of 10 species belonging to 10 families, including Convolvulaceae, Lamiaceae, and Rhamnaceae where photoactivity has not been previously reported. Interestingly, Leucas zeylanica (L.) R. Br. (Lamiaceae), one of only three species collected from more than one site, showed population-level variation in photoactivity. This is the first study where plants from highly stressful serpentine environments have been tested for antimicrobial activity. Our findings suggest that plants from serpentine environments may have altered antimicrobial activities when compared to their relatives from non-serpentine environments, urging the need to pay attention to substrate, habitat, etc., when collecting plants to test for antimicrobial properties.
\end{abstract}

Keywords: Antimicrobial, edaphic stress, photoactivity, serpentine, Sri Lankan flora, ultramafic.

\section{Introduction}

The quest for plants with medicinal properties continues to receive attention as scientists survey plants, particularly of ethnobotanical significance, for a complete range of biological activities, which range from antibiotic to antitumor. Thus far, plants have provided western medicine with an abundance of drugs and treatments for a variety of health problems (Lewis \& Elvin-Lewis, 1977; Bruneton, 1999). While species used in traditional medicines continue to be the most reliable sources for the discovery of useful compounds, the screening of plants growing under various stresses (Ben et al., 1992; Hanawa et al., 1992; Kruger \& Manion, 1994; Broekaert et al., 1997; Mohamed \& Sehgal, 1997; Dubery et al., 1999; Pernas et al., 2000) has provided yet another source for compounds with useful activities against microbes. The present study investigated antimicrobial properties of species found on serpentine outcrops in Sri Lanka, a natural environment imposing extreme edaphic stress on plants.

Serpentine soils are the weathered product of ultramafic rocks. Extensive ultramafic rock covers are found along continental margins and on offshore islands and are often associated with obducted oceanic crusts and plate tectonics (Coleman \& Jove, 1992). The soils produced from the weathering of these rocks are often shallow and rocky and consist of high concentrations of $\mathrm{Fe}$ and $\mathrm{Mg}$ as well as heavy metals such as $\mathrm{Ni}, \mathrm{Cr}, \mathrm{Cd}$, and $\mathrm{Co}$. Essential nutrients such as $\mathrm{N}$, $\mathrm{P}, \mathrm{K}$, and $\mathrm{Ca}$ and micro-nutrients such as $\mathrm{Mo}$ and $\mathrm{B}$ are extremely low making these soils nutrient poor and ionically imbalanced for plant growth. The cation exchange capacities are often lower than in agricultural soils; $\mathrm{pH}$ values are often high ranging from 6-9. Further, the sparse vegetation cover characteristic of these environments, makes these soils susceptible to high temperature effects leading to extreme moisture stress. In short, serpentine soils can provide challenging, if not outright hostile, environments for plants (Proctor \& Woodell, 1975; Kruckeberg, 1984; Brooks, 1987; Baker et al., 1992). Plants growing in serpentine soils, however, are physiologically adapted to deal with the stresses of the 
environment: plants possess various morphological features to deal with the physical stresses of the environment and physiological mechanisms to cope with the unusual chemical environment. It is possible that various compounds that are induced by stress, either for tolerance or as a by-product of some physiological process, may in fact possess antimicrobial properties. Hence, plants growing in serpentine environments may be good candidates for the study of plants with antimicrobial properties.

Recent studies in this laboratory have shown the induction of antifungal compounds in plants exposed to $\mathrm{Cu}$ stress (Hanawa et al., 2000). Work by other researchers (Tahara et al., 1994; Hashem \& Sahab, 1999) has also shown the induction of antimicrobial compounds by plants exposed to high $\mathrm{Cu}$. As well, compounds induced by salinity stress have been associated with defense proteins possessing antifungal activity (Vigers et al., 1991; Pernas et al., 2000). Studies done on species growing in high metal environments such as serpentine habitats have shown that plants that accumulate heavy metals may have better defenses against herbivores and pathogens (Boyd, 1998). Boyd et al. (1994) have shown that the Ni hyperaccumulating plant, Streptanthus polygaloides Gray (Brassicaceae), may be effective against the pathogenic fungus Erysiphe polygoni, pathogenic bacterium Xanthomonas campestris pv. campestris, and the necrotrophic fungus, Alternaria brassicicola. Other studies (Weiersbye \& Przybylowicz, 1999; Ghaderian et al., 2000) further support the hypothesis that metal hyperaccumulation by plants is closely linked to enhanced protection against disease.

The present study was conducted to determine the antimicrobial activities of species collected during an exploration of four of the five known serpentine outcrops in Sri Lanka (Rajakaruna \& Bohm, 2002). The species collected are not endemic to Sri Lanka or restricted to the substrate, however, findings suggest that several species may represent physiological races or ecotypes unique to the substrate. Several species accumulated metals to levels considered toxic to physiological processes of plants. Three species, Crotalaria biflora (L.) L. (Fabaceae), Evolvulus alsinoides (L.) L. (Convolvulaceae), and Hybanthus enneaspermus (L.) F. Muell. (Violaceae), hyperaccumulated ( $>1000 \mu \mathrm{g} / \mathrm{g}$ dry tissue) Ni. Five species, Clerodendrum infortunatum L. (Verbenaceae), Croton bonplandianus Baill. (Euphorbiaceae), Geniosporum tenuiflorum (L.) Merr. (Lamiaceae), Tephrosia villosa Pers. (Fabaceae), and Waltheria indica L. (Sterculiaceae), hyperaccumulated $\mathrm{Cu}(>1000 \mu \mathrm{g} / \mathrm{g}$ dry tissue), although $\mathrm{Cu}$ is not considered to be unusually high in serpentine soils. One species, Calotropis gigantea (L.) R. Br. (Asclepiadaceae), accumulated sodium to levels often seen in halophytic plants (Rajakaruna \& Bohm, 2002).

Interestingly, many of the species surveyed in the study (24 out of 32) have a history of traditional use in Sri Lanka (Jayaweera, 1980-1982; Dassanayke, 1980-2000; Ashton et al., 1997) and in the neighboring sub-continent of India (Dash, 1991; Pal \& Jain, 1998) suggesting that medicinal properties of these species are not limited to populations found on serpentine soils. However, it is of interest to find out if serpentine populations, especially those species hyperaccumulating metal, have unusual activity compared to previously reported activities of the same species collected from non-serpentine substrates. In addition, the history of medicinal use for many of these species makes them good candidates for the present study (Table 1).

\section{Materials and methods}

\section{Field collections}

Plants were collected from four of the five known serpentine outcrops in Sri Lanka during March and April, 1999. The locations of the collection sites are indicated in Figure 1 and described previously by Rajakaruna and Bohm (2002).

Due to time constraints for field work and to aid in subsequent identification, only species in the reproductive stage were collected. For herbaceous species, whole plants were collected and for trees and shrubs, stems with leaves and reproductive structures were collected. Specimens were cleaned of adhering soil/dust in the field by shaking and quick rinsing with tap water. Plants were placed in paper bags and transferred to the laboratory. Any remaining particles of soil were removed by use of pressurized airflow and by the use of a paint brush and, in some cases, by quick rinsing with distilled water. All plants were allowed to dry at room temperature and were tested for activity approximately one and half years after collection. The plant species used in this study are documented in Table 2. Specimens of all species will be deposited at the University of British Columbia Herbarium, Vancouver, BC, Canada.

\section{Extract and disk preparation}

Each plant sample was thoroughly ground using a Model CG 150 Sunbeam Café Mill. For each species, one gram of tissue was extracted with $10 \mathrm{~mL}$ of $100 \%$ methanol and stored in darkness for $72 \mathrm{~h}$. Each crude extract was filtered through Whatman \#3 filter paper and the filtrate was rotoevaporated to dryness. One gram of the dried filtrate was reconstituted with $10 \mathrm{~mL}$ of $100 \%$ methanol. Paper disks (diameter $6 \mathrm{~mm}$ ) were then impregnated with $20 \mu \mathrm{L}$ of the final extract, the equivalent of $2 \mathrm{mg} / \mathrm{mL}$ of dried plant material. Once the methanol had evaporated, the disks were placed in a refrigerator and stored in darkness at $4{ }^{\circ} \mathrm{C}$ for the duration of the assays.

\section{Microorganisms}

A total of seven microorganisms were used in the screening: Staphylococcus aureus (methicillin-resistant), Bacillus subtilis, and Enterobacter faecalis were the three Gram-positive bacteria while Escherichia coli and Pseudomonas aeruginosa $\mathrm{H} 187$ (wild type) were the two Gram-negative bacteria. Mycobacter phlei was a non-acid fast bacterium tested, while 
Table 1. Traditional uses for the plants from Sri Lanka surveyed in this study.

\begin{tabular}{|c|c|c|}
\hline Family and species & Traditional medicinal uses & Source $^{\mathrm{a}}$ \\
\hline \multicolumn{3}{|l|}{ AMARANTHACEAE } \\
\hline Aerva lanata & Root paste used with other roots to cure piles; Medicinal tea & $\begin{array}{l}4 \\
3\end{array}$ \\
\hline \multicolumn{3}{|l|}{ ASCLEPIADACEAE } \\
\hline Calotropis gigantea & $\begin{array}{l}\text { Roots and leaves, sometimes with other plants, to treat skin diseases, leprosy, } \\
\text { dysentery, worms, ulcers, tumors, liver-diseases and ear-aches }\end{array}$ & $1,2,3,4$ \\
\hline Epaltes divaricata & Roots used as a tonic & 3 \\
\hline Eupatorium odoratum & Juice of aerial parts applied to cuts and wounds & 5 \\
\hline Spilanthes calva & Paste for toothaches; mixed with other plants for piles, dropsy & 4 \\
\hline \multicolumn{3}{|l|}{ CONVOLVULACEAE } \\
\hline Evolvulus alsinoides & $\begin{array}{l}\text { Root and stem extract to treat dysentery to depression; leaves for asthma; mental } \\
\text { disturbances }\end{array}$ & $1,2,3,4$ \\
\hline \multicolumn{3}{|l|}{ FABACEAE } \\
\hline Cassia auriculata & Leaves for tea; root for fevers, diabetes, constipation and urinary disease & 2,3 \\
\hline Tephrosia purpurea & $\begin{array}{l}\text { Cures liver and spleen disorders, cough and fever; treats dyspepsia and colic; in } \\
\text { mixtures for impotency }\end{array}$ & $1,2,4$ \\
\hline Tephrosia villosa & Leaf juice for dropsy; roots used in toothpaste & 2 \\
\hline \multicolumn{3}{|l|}{ LAMIACEAE } \\
\hline Leucas zeylanica & $\begin{array}{l}\text { Principle ingredient in vermifuge; treats anorexia, flatulence, colic; in mixture to } \\
\text { treat malaria }\end{array}$ & 2,3 \\
\hline Ocimum sanctum & Cures skin disease (leprosy), fevers, dysuria and chest pain (often with other plants) & 1,4 \\
\hline \multicolumn{3}{|l|}{ MALVACEAE } \\
\hline \multicolumn{3}{|l|}{ MYRTACEAE } \\
\hline \multicolumn{3}{|l|}{ POACEAE } \\
\hline Aristida setacea & Used to treat foot and mouth diseases in animals & 4 \\
\hline \multicolumn{3}{|l|}{ RHAMNACEAE } \\
\hline Zizyphus oenoplia & $\begin{array}{l}\text { Stem bark used as mouthwash for sore throat, for dysentery and inflammation of } \\
\text { the uterus }\end{array}$ & 4 \\
\hline \multicolumn{3}{|l|}{ RUBIACEAE } \\
\hline Morinda tinctoria & $\begin{array}{l}\text { Internally as astringent, externally for gout and rheumatism; relieves diarrhea and } \\
\text { cholera }\end{array}$ & 2,4 \\
\hline Tarenna asiatica & Fruits are mashed and applied to boils & 2 \\
\hline \multicolumn{3}{|l|}{ RUTACEAE } \\
\hline Toddalia asiatica & Reputed antimalarial; used for asthma and as a stimulating tonic & 2,3 \\
\hline \multicolumn{3}{|l|}{ SOLANACEAE } \\
\hline Physalis minima & Used to treat skin disorders (leprosy) and diseases causing bleeding & 1 \\
\hline \multicolumn{3}{|l|}{ VERBENACEAE } \\
\hline $\begin{array}{l}\text { Clerodendrum } \\
\text { infortunatum }\end{array}$ & $\begin{array}{l}\text { Tonic as antiperiodic, laxative, vermifuge and febrifuge; paste for external tumors } \\
\text { and skin diseases; juice for snakebites }\end{array}$ & 2,3 \\
\hline Lantana camara & $\begin{array}{l}\text { Decoction for treatment of tetanus, fever, measles/chicken pox, constipation, } \\
\text { catarrh and bronchitis }\end{array}$ & 3,4 \\
\hline
\end{tabular}

${ }^{a}$ Sources cited: 1 - Dash, 1991; 2 - Jayaweera, 1980-1982; 3 - Dassanayake (ed.), 1980-2000; 4 - Pal and Jain, $1998 ; 5$ - Taylor et al., 1996. 


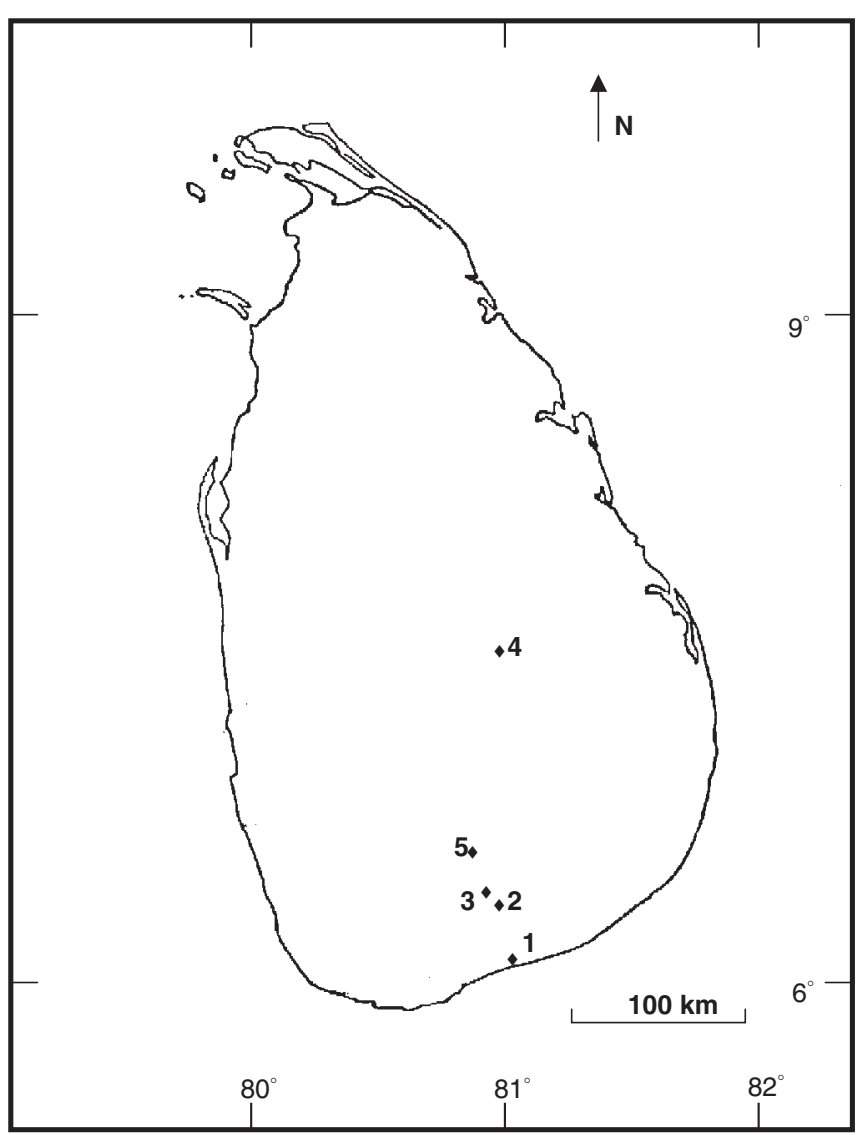

Figure 1. The locations of the five serpentine outcrops of Sri Lanka. Sites 1: Ussangoda; 2: Indikolapelessa; 3: Ginigalpelessa; 4: Yodhagannawa; 5: Katupotha (unexplored).

Candida albicans was the only fungal microorganism used in the study. All cultures were from the collection of Dr. G.H.N. Towers, Department of Botany, University of British Columbia, Vancouver, Canada.

An inoculum of each microorganism was suspended in $3 \mathrm{~mL}$ of nutrient broth. The bacteria species were cultured in the Mueller-Hinton broth while the yeast species was cultured in SAB broth (Becton Dickinson \& Company, MD, U.S.A). All cultures were incubated on a shaker at $37^{\circ} \mathrm{C}$ for $18 \mathrm{~h}$ and then diluted to $1 / 10$ the concentration to yield a culture density of approximately $10^{8} \mathrm{CFU} / \mathrm{mL}$.

\section{Antimicrobial assays}

The disk diffusion assay (Lennette, 1985) was used to screen for antimicrobial activity. Using cotton swabs, the cultures were evenly spread over the appropriate media: bacteria on Mueller-Hinton agar and the yeast on SAB agar. Duplicates were made for each assay and the impregnated disks were placed on plates under darkness. All plates were then covered and incubated for $30 \mathrm{~min}$ at $37^{\circ} \mathrm{C}$. One plate from each assay was then placed under long wave UV light (Sylvania, F20T12/BLB, 20W, four bulbs) for $45 \mathrm{~min}$ at room tempera- ture while the other remained in the darkness. After the irradiation treatment, plates were returned to the incubator and incubated for $24 \mathrm{~h}$. At the end of the incubation period, zones of inhibition around each disk were measured and graded according to the diameter of the zone of inhibition. Antimicrobial activity resulting from or enhanced by the UV treatment was reported as phototoxic. Disks impregnated with $20 \mu \mathrm{L}$ of methanol were used as negative controls while disks impregnated with $10 \mu \mathrm{L}$ each of Gentamicin, Nystatin, and 8-methoxypsoralen "8-MOP" (Sigma-Aldrich Canada Ltd., Ontario, Canada) were used as positive controls for antibacterial and antifungal activity, and photoactivity, respectively. Each assay, for both dark and light treatments, was performed three times except for samples that showed no activity over the first two trials.

\section{Results}

A total of 29 out of the 32 species screened demonstrated activity against at least one microorganism (Table 3). Extracts of Croton bonplandianus, Toddalia asiatica Lamk. (Rutaceae), and Hybanthus enneaspermus demonstrated no antimicrobial activity. Extracts from 26 species inhibited the growth of the non-acid fast bacterium, M. phlei, the most susceptible of the tested microorganisms. Eight extracts were active only toward $M$. phlei while two extracts exhibited activity against other bacteria yet failed to inhibit the growth of M. phlei. Extracts from 20 species inhibited the growth of at least one Gram-positive bacterium. Six species were active against all three Gram-positive bacteria tested, however, activity towards E. faecalis was limited to those extracts active towards both $S$. aureus and B. subtilis. The six species, in order of their effectiveness against the three Grampositive bacteria, are Clerodendrum infortunatum, Phoenix farnifera Roxb. (Arecaceae), Fimbristylis falcata (Vahl.) Kunth (Cyperaceae), Phyllanthus sp., Lantana camara, and Catunaregam spinosa (Thunb.) D. D. Tirvengadum (Rubiaceae). A total of 16 and 18 species were active against $S$. aureus and B. subtilis, respectively, while 14 species were toxic to both bacteria. Syzygium cumini Skeels (Myrtaceae) and Leucas zeylanica produced the largest zones of inhibition against these two bacteria. The activity of the two species was either light induced or light enhanced documenting photoactivity for the two species. In all cases where an extract was inhibitory towards only $S$. aureus or B. subtilis, the activity of the extract was either light induced or light enhanced.

None of the species tested was active against the Gramnegative bacterium, E. coli or the yeast, C. albicans. Extracts from both Lantana camara and the unidentified species of Phyllanthus inhibited the growth of the Gram-negative bacterium, P. aeruginosa. Activities of both these species were light activated. Lantana camara and the Phyllanthus species demonstrated the broadest range of activity, with non-photosensitive activity against all the Gram-positive bacteria and M. phlei. 
Table 2. Species collected from the four serpentine outcrops in Sri Lanka.

\begin{tabular}{|c|c|c|}
\hline Species & Family & Sites $^{\mathrm{a}}$ \\
\hline Abutilon indicum Sweet & Malvaceae & 3 \\
\hline Aerva lanata (L.) Juss. Ex Schult. & Amaranthaceae & 2 \\
\hline Aristida setacea Retz. & Poaceae & 2 \\
\hline Calotropis gigantea (L.) R. Br. & Asclepiadaceae & 2 \\
\hline Canthium sp. Lam. & Rubiaceae & 2 \\
\hline Cassia auriculata $\mathrm{L}$. & Fabaceae & 1 \\
\hline Catunaregam spinosa (Thunb.) D.D. Tirvengadum & Rubiaceae & 2 \\
\hline Clerodendrum infortunatum $\mathrm{L}$. & Verbenaceae & 2 \\
\hline Crotalaria biflora (L.) L. & Fabaceae & 1 \\
\hline Croton bonplandianus Baill. & Euphorbiaceae & 2 \\
\hline Epaltes divaricata (L.) Cass. & Asteraceae & 1 \\
\hline Eupatorium odoratum $\mathrm{L}$. & Asteraceae & 2,3 \\
\hline Euphorbia rubicunda Blume & Euphorbiaceae & 2 \\
\hline Evolvulus alsinoides (L.) L. & Convolvulaceae & 1 \\
\hline Fimbristylis falcata (Vahl.) Kunth & Cyperaceae & 1 \\
\hline Geniosporum tenuiflorum (L.) Merr. & Lamiaceae & 4 \\
\hline Hybanthus enneaspermus (L.) F. Muell. & Violaceae & 1 \\
\hline Lantana camara $\mathrm{L}$. & Verbenaceae & 2 \\
\hline Leucas zeylanica (L.) R. Br. & Lamiaceae & $2,3,4$ \\
\hline Morinda tinctoria Roxb. & Rubiaceae & 2 \\
\hline Ocimum sanctum $\mathrm{L}$. & Lamiaceae & 2 \\
\hline Phoenix farinifera Roxb. & Arecaceae & 2,3 \\
\hline Phyllanthus sp. L. & Euphorbiaceae & 2 \\
\hline Physalis minima $\mathrm{L}$. & Solanaceae & 3 \\
\hline Sida acuta Burm. & Malvaceae & 3 \\
\hline Spilanthes calva DC. & Asteraceae & 3 \\
\hline Syzygium cumini Skeels & Myrtaceae & 2 \\
\hline Tarenna asiatica (L.) Alston & Rubiaceae & 1 \\
\hline Tephrosia purpurea Pers. & Fabaceae & 4 \\
\hline Tephrosia villosa Pers. & Fabaceae & 3 \\
\hline Toddalia asiatica Lamk. & Rutaceae & 1 \\
\hline Zizyphus oenoplia Mill. & Rhamnaceae & 2 \\
\hline
\end{tabular}

${ }^{\text {a }}$ Sites: 1 - Ussangoda, 2 - Ginigalpelessa, 3 - Indikolapelessa, 4 - Yodhagannawa.

Photoactivity was observed in 10 plant species from 10 families. For the families Convolvulaceae, Lamiaceae, and Rhamnaceae, this is the first report of photoactivity. In terms of the microorganisms tested, S. aureus, B. subtilis, and $P$. aeruginosa were susceptible to UV-induced activity while growth inhibition of E. faecalis and $M$. phlei remained constant between light and dark treatments.

The negative control of methanol had no effect on microbial growth. The positive controls had varied activity: Gentamicin inhibited the growth of the six bacterial species to a greater degree than the plant extracts although this was matched by three species (Phoenix farinifera, Fimbristlylis falcata, Clerodendrum infortunatum) in activity toward $E$. faecalis. Nystatin effectively inhibited the growth of $C$. albicans, but the activity was lost after UV irradiation. The positive control for photoactivity, 8-MOP, was effective at inhibiting the growth of all but one of the microorganisms tested; this compound had no effect on the growth of $P$. aeruginosa.
Three species, Phoenix farinifera, Leucas zeylanica, and Eupatorium odoratum L. (Asteraceae), were collected from more than one location. Although, both $P$. farinifera and $E$. odoratum exhibited similar activities against the screened microorganisms, L. zeylanica showed significant populationlevel variation. For L. zeylanica, activity against the microorganisms, except $M$. phlei, was photo-mediated and restricted to $S$. aureus or B. subtilis. Whereas one population showed photo enhanced activity towards $S$. aureus and photoactivity towards B. subtilis, the activity of the second population was reversed. Interestingly, the third population of $L$. zeylanica was photoactive against $B$. subtilis but inactive against $S$. aureus.

\section{Discussion}

The majority of studies conducted in the search of compounds with antimicrobial properties have targeted plants 
Table 3. Antimicrobial activity ${ }^{\mathrm{a}}$ of methanol extracts of plant species collected from serpentine outcrops in Sri Lanka.

\begin{tabular}{|c|c|c|c|c|c|c|c|}
\hline Family and Species & S. $a u r^{\mathrm{c}}$ & B. sub & E. fae & E. coli & P. aer & C. alb & M. phlei \\
\hline \multicolumn{8}{|l|}{ CONTROLS } \\
\hline Methanol & 0 & 0 & 0 & 0 & 0 & 0 & 0 \\
\hline Gentamicin $(10 \mu \mathrm{l})$ & $5+$ & $5+$ & $2+$ & $5+$ & $4+$ & 0 & $4+$ \\
\hline Nystatin $(10 \mu \mathrm{l})$ & 0 & 0 & 0 & 0 & 0 & $3+(\mathrm{Pd})$ & 0 \\
\hline 8-MOP $(10 \mu \mathrm{l})$ & $3+(\mathrm{P})$ & $2+(\mathrm{P})$ & $3+(\mathrm{P})$ & $2+(\mathrm{P})$ & 0 & $3+(\mathrm{P})$ & $3+(\mathrm{P})$ \\
\hline \multicolumn{8}{|l|}{ AMARANTHACEAE } \\
\hline \multicolumn{8}{|l|}{ ARECACEAE } \\
\hline Phoenix farinifera $[\mathrm{A}]^{\mathrm{b}}$ & $2+$ & $2+$ & $2+$ & 0 & 0 & 0 & $3+$ \\
\hline Phoenix farinifera $[\mathrm{B}]$ & $2+$ & $2+$ & $2+$ & 0 & 0 & 0 & $3+$ \\
\hline \multicolumn{8}{|l|}{ ASCLEPIADACEAE } \\
\hline Calotropis gigantea & 0 & 0 & 0 & 0 & 0 & 0 & $1+$ \\
\hline \multicolumn{8}{|l|}{ ASTERACEAE } \\
\hline Epaltes divaricata & 0 & 0 & 0 & 0 & 0 & 0 & $1+$ \\
\hline Eupatorium odoratum $[\mathrm{A}]$ & $1+$ & $1+$ & 0 & 0 & 0 & 0 & $3+$ \\
\hline Eupatorium odoratum $[\mathrm{B}]$ & $1+$ & $1+$ & 0 & 0 & 0 & 0 & $2+$ \\
\hline Spilanthes calva & $1+$ & $2+$ & 0 & 0 & 0 & 0 & $3+$ \\
\hline \multicolumn{8}{|l|}{ CONVOLVULACEAE } \\
\hline Evolvulus alsinoides & 0 & $1+(\mathrm{P})$ & 0 & 0 & 0 & 0 & $2+$ \\
\hline \multicolumn{8}{|l|}{ CYPERACEAE } \\
\hline Fimbristylis falcata & $2+$ & $2+$ & $2+$ & 0 & 0 & 0 & $2+$ \\
\hline \multicolumn{8}{|l|}{ EUPHORBIACEAE } \\
\hline Croton bonplandianus & 0 & 0 & 0 & 0 & 0 & 0 & 0 \\
\hline Euphorbia rubicunda & $3+$ & $1+$ & 0 & 0 & 0 & 0 & $2+$ \\
\hline Phyllanthus sp. & $3+$ & $2+$ & $1+$ & 0 & $3+\left(\mathrm{P}^{*}\right)$ & 0 & $3+$ \\
\hline \multicolumn{8}{|l|}{ FABACEAE } \\
\hline Cassia auriculata & 0 & $2+(\mathrm{P})$ & 0 & 0 & 0 & 0 & $2+$ \\
\hline Crotalaria biflora & 0 & 0 & 0 & 0 & 0 & 0 & $1+$ \\
\hline Tephrosia purpurea & 0 & 0 & 0 & 0 & 0 & 0 & $1+$ \\
\hline Tephrosia villosa & 0 & 0 & 0 & 0 & 0 & 0 & $2+$ \\
\hline \multicolumn{8}{|l|}{ LAMIACEAE } \\
\hline Geniosporum tenuiflorum & $2+$ & $3+$ & 0 & 0 & 0 & 0 & $3+$ \\
\hline Leucas zeylanica [A] & $3+(\mathrm{P})$ & $4+\left(\mathrm{P}^{*}\right)$ & 0 & 0 & 0 & 0 & $2+$ \\
\hline Leucas zeylanica $[\mathrm{B}]$ & $3+\left(\mathrm{P}^{*}\right)$ & $4+(\mathrm{P})$ & 0 & 0 & 0 & 0 & $3+$ \\
\hline Leucas zeylanica $[\mathrm{C}]$ & 0 & $2+(\mathrm{P})$ & 0 & 0 & 0 & 0 & $2+$ \\
\hline Ocimum sanctum & $1+$ & $2+$ & 0 & 0 & 0 & 0 & $3+$ \\
\hline \multicolumn{8}{|l|}{ MALVACEAE } \\
\hline Sida acuta & $2+\left(\mathrm{P}^{*}\right)$ & 0 & 0 & 0 & 0 & 0 & $3+$ \\
\hline \multicolumn{8}{|l|}{ MYRTACEAE } \\
\hline Syzygium cumini & $4+\left(\mathrm{P}^{*}\right)$ & $4+\left(\mathrm{P}^{*}\right)$ & 0 & 0 & 0 & 0 & $3+$ \\
\hline \multicolumn{8}{|l|}{ POACEAE } \\
\hline Aristida setacea & 0 & 0 & 0 & 0 & 0 & 0 & 0 \\
\hline \multicolumn{8}{|l|}{ RHAMNACEAE } \\
\hline Zizyphus oenoplia & $1+(\mathrm{P})$ & 0 & 0 & 0 & 0 & 0 & 0 \\
\hline \multicolumn{8}{|l|}{ RUBIACEAE } \\
\hline Canthium $s p$. & $1+$ & $1+$ & 0 & 0 & 0 & 0 & $1+$ \\
\hline Catunaregam spinosa & $1+$ & $1+$ & $1+$ & 0 & 0 & 0 & $2+$ \\
\hline Morinda tinctoria & 0 & $3+(\mathrm{P})$ & 0 & 0 & 0 & 0 & 0 \\
\hline Tarenna asiatica & 0 & 0 & 0 & 0 & 0 & 0 & $1+$ \\
\hline
\end{tabular}


Table 3. Continued

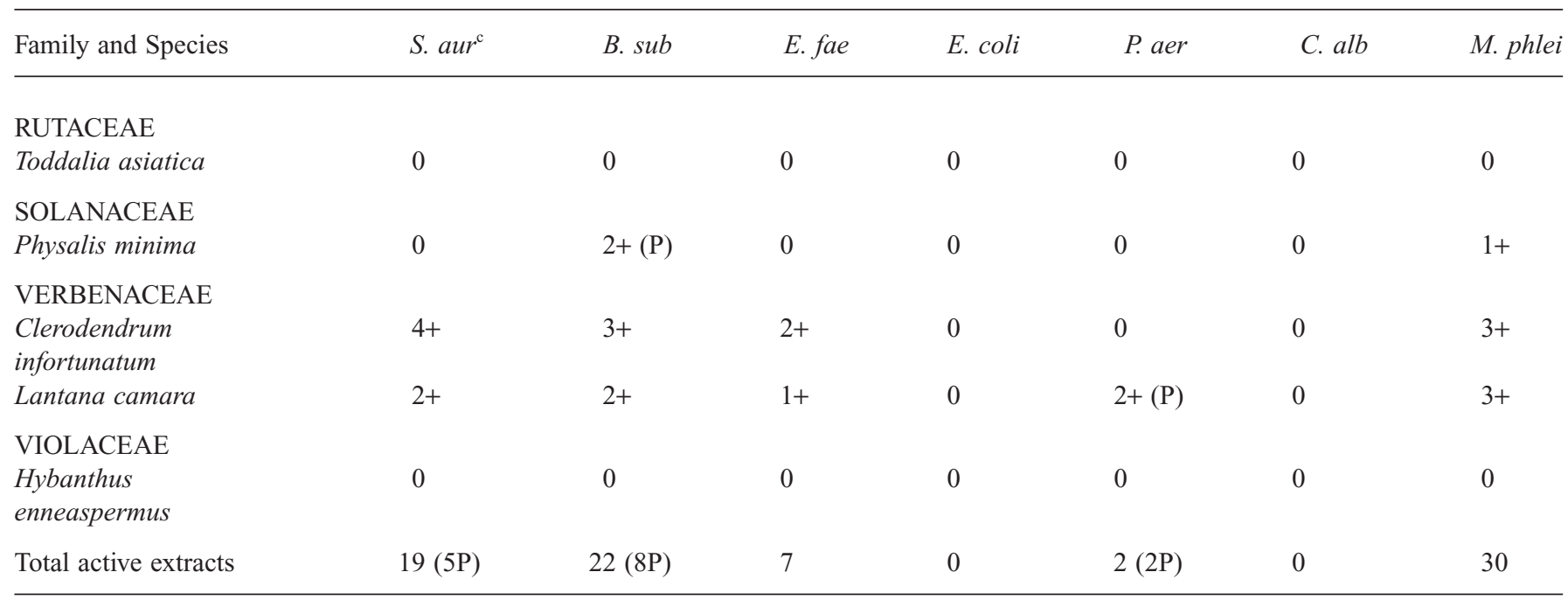

${ }^{a}$ Diameter of zones of inhibition: $\mathbf{0}$, no inhibition or zone of inhibition $<8 \mathrm{~mm}$; 1+, 8.0-9.9 mm; 2+, 10.0-13.9 mm; 3+, 14.0-17.9; 4+, 18.0-21.9; 5+, zone of inhibition $>22 \mathrm{~mm}$.

(P): photo-induced activity; $\left(\mathrm{P}^{*}\right)$ : photo-enhanced activity; $(\mathrm{Pd})$ : photo-deactivation.

${ }^{\mathrm{b}}$ [A, B, or C]: collection sites of Ginigalpelessa, Indikolapelessa, and Yodhagannawa, respectively.

${ }^{\mathrm{c}}$ Microorganisms: S. aur - Staphylococcus aureus; B. sub-Bacillus subtilis; E. fae-Enterobacter faecalis; E. coli-Escherichia coli; P. aer-Pseudomonas aeruginosa H187; C. alb-Candida albicans; M. phlei-Mycobacter phlei.

with a history of ethnobotanical uses (Jovel et al., 1996; Taylor et al., 1996; Sindambiwe et al., 1999; Sokmen et al., 1999; Srinivasan et al., 2001; Alves et al., 2000) while a few studies have targeted randomly collected plants (Khafagi \& Dewedar, 2000), plants with localized distribution patterns (Herrera et al., 1996), and plants growing in specific habitats (Devi et al., 1997; Bagchi et al., 1999). The present study of plants growing on serpentine outcrops provides the first instance where plants from a heavy metal-rich, edaphicallystressed natural habitat have been screened for potential antimicrobial properties.

Several species that were screened in this study have previously been surveyed for antimicrobial activities. In a recent survey by Samy and Ignacimuthu (2000), Aerva lanata (L.) Juss. Ex Schult. (Amaranthaceae), Abutilon indicum Sweet (Malvaceae), Tephrosia pupurea Pers.(Fabaceae), Sida acuta Burm (Malvaceae), Syzygium cumini and Toddalia asiatica were found not to exhibit any antimicrobial properties. Similarly, our study failed to show any activity for T. asiatica, however, for the other five species tested, considerable activity was shown against several bacteria. Species of $A$. lanata and $A$. indicum have previously been documented as ineffective against the growth of $S$. aureus, B. subtilis, E. coli, $P$. aeruginosa and several other bacteria (Valsaraj et al., 1997; Samy et al., 1999). Our results agree with their findings, however, these studies did not include the non-acid-fast bacterium, M. phlei, against which both these species showed activity in the present study. Interestingly, a recent study by Srinivasan et al. (2001) has shown antibacterial activity of $A$. indicum against two Gram-negative and one Gram-positive species. Previous studies (Samy et al., 1998; Srinivasan et al.,
2001) found that T. purpurea, S. cumini, and S. acuta exhibited no activity against Gram-negative bacteria, including those tested in our study, agreeing with the observations made in the current study. A study by Bagchi et al. (1999), however, has shown considerable activity of $S$. cuminii growing on cow dung against Gram-positive and Gramnegative bacteria and fungi suggesting the possible influence of their microbe-rich edaphic environment in the activity displayed. A new finding of our study is the photoactivity of both S. acuta and S. cumini. Sida acuta exhibited photo enhanced activity against $S$. aureus while $S$. cumini produced the largest zones of inhibition documented for both $S$. aureus and B. subtilis.

Seven species, Calotropis gigantea, Cassia auriculata L. (Fabaceae), Clerodendrum infortunatum, Eupatorium odoratum, Lantana camara, Morinda tinctoria Roxb. (Rubiaceae), and Physalis minima L. (Solanaceae) surveyed in our study have displayed antimicrobial properties in previous studies (Taylor et al., 1996; Valsaraj et al., 1997; Bagchi et al., 1999; Samy \& Ignacimuthu, 2000; Srinivasan et al., 2001). Our results agree with the findings of several of these studies, although, some conflicting observations are worthy of note. For instance, Cassia auriculata, Calotropis gigantea, Clerodendrum infortunatum, Lantana camara, and Morinda tinctoria have been previously shown to be effective against the Gram-negative bacterium, E. coli (Valsaraj et al., 1997; Sami \& Ignacimuthu, 2000). None of these species were effective against $E$. coli in our study. A study by Srinivasan et al. (2001) documented that $C$. auriculata was active against the Gram-negative $P$. aeruginosa but not against $E$. coli as documented by the earlier researchers. In our study, 
only $L$. camara tested effective against $P$. aeruginosa, yet it was ineffective against $E$. coli. Further, Eupatorium odoratum was previously recorded as having light enhanced activity (Taylor et al., 1996), whereas in our study the activities of this species were not activated or enhanced by light. While these discrepancies may reveal population-level differences in activity, which could be genetic or environmentallyinduced or both, it may also result from the concentration differences used in the different studies. The concentration used in our study is several fold lower than those used in the other studies.

None of the metal hyperaccumulators showed any noteworthy effects against the microorganisms tested. This is in contrast to earlier findings (Boyd et al., 1994; Ghaderian et al., 2000) where the Ni in the hyperaccumulator was suggested to aid in the defense against pathogenic microbes. However, our study is different in that we did not directly test the effect of $\mathrm{Ni}$ on microbial growth. In fact, the concentrations of $\mathrm{Ni}$ in our crude methanol extracts were not tested and are most likely low. The Ni-hyperaccumulating species, Hybanthus enneaspermus, showed no activity against any of the organisms tested while Crotalaria biflora showed activity against only M. phlei. Evolvulus alsinoides, another Nihyperaccumulator, showed mild photoactivity against $B$. subtilis. This is the first record for photoactivity in the family Convolvulaceae. Whether this activity is related to the influence of the edaphic environment is unclear at this stage. The hyperaccumulation of $\mathrm{Cu}$ also showed little correlation to antimicrobial activity. Out of the several $\mathrm{Cu}$ hyperaccumulators tested, only Geniosporum tenuiflorum and Clerodendrum infortunatum showed activity against Gram-positive bacteria. It is unclear whether the gain or loss of antimicrobial activity in the plants collected in our study can be attributed to the influence of the edaphic environment or their metal-accumulating behavior. While the stressful environment of cow dung (Bagchi et al., 1999) has been shown to host a large number of plant species with enhanced activities against a range of microorganisms, the species we tested from the serpentine sites seem to have reduced activities compared to those reported for populations collected from non-serpentine sites; given the wide distribution of the species we tested, it is likely that populations previously tested came from non-serpentine substrates. An extensive survey of species from serpentine and non-serpentine sites is in order to determine if species found on serpentine substrates have reduced activity against microbes.

Two studies suggest possible reasons for the apparent loss of activity we have observed in the serpentine plants. Firstly, a study looking at the effects of water stress on the induction of antimicrobial compounds has shown that under water stress plants produce significantly lower concentrations of antimicrobial compounds (Kruger \& Manion, 1994). Serpentine environments are generally under extreme water stress, hence, the apparent loss of activity in the serpentine plants we collected may be due to water stress. Secondly, a study of microbe populations in serpentine and sandstone grasslands has shown that serpentine soils are significantly lower in fungal biomass and higher in fungivorous nematodes than soils derived from sandstone (Hungate et al., 2000). Hence, the need for defense against various microbes may be lost in serpentine populations long-isolated from their close relatives found growing in non-serpentine soils.

In the current study only 12 of the 23 known medicinal species demonstrated activity beyond M. phlei and only two of the 32 species tested showed activity against the Gramnegative bacteria. When collections are based primarily on ethnobotanical information (McCutcheon et al., 1992; Taylor et al., 1996; Perez \& Suarez, 1997; Khafagi \& Dewedar, 2000 ) or on close relatives of plants with previously recorded activities against microorganisms (Camm et al., 1975; Ali et al., 1999; Dahot, 1999), the occurrence of antimicrobial activity is much higher than recorded in our study. Further, our preliminary survey used only seven microorganisms compared to much higher numbers tested in other studies.

The population level differences we have documented for the activities of Leucas zeylanica emphasizes the importance of considering population level variation in testing for antimicrobial properties in plants. Although the three populations of this species were similar in phenology and were collected from near-identical habitats, the populations showed considerable variation in their activities against the tested organisms.

The high incidence of photoactivity found in the current study reinforces the need for testing plants under light conditions (Towers, 1984). In angiosperms, activity of certain secondary metabolites, some of which are known to be associated with plant defense, is affected by exposure to light (Hudson \& Towers, 1991; Towers et al., 1997). In our study, 10 of the 32 species tested demonstrated some degree of photoactivity. The photoactivities of Evolvulus alsinoides, Leucas zeylanica, and Zizyphus oenoplia Mill. (Rhamnaceae) are the first reports of photoactivity for the families of Convolvulaceae, Lamiaceae, and Rhamnaceae, respectively. The photoactivities of several plants we tested may be explained by previous studies done on the chemistry of these species. The photoactivity of Cassia auriculata (Fabaceae) may be due to the presence of furanocoumarins and furochromones known in the family (Towers et al., 1997) while the photoactivity of Syzygium cumini (Myrtaceae) may be due to the presence of monoterpene aldehydes (Berenbaum, 1995). The photoactivities demonstrated by Physalis minima (Solanaceae) and Morinda tinctoria (Rubiaceae) may be resulting from beta-carbolines and furanocoumarins common in the Solanaceae and beta-carbolines, isoquinolines, and quinolines known from the Rubiaceae, respectively (Berenbaum, 1995). Lantana camara (Verbenaceae) and the unidentified species of Phyllanthus (Euphorbiaceae) were the two most promising species in terms of photoactivities against a range of microorganisms, including the Gram-negative bacterium $P$. aeruginosum. While Euphorbiaceae is known to contain the photoactive isoquinolines (Berenbaum, 1995), directly photoactive com- 
pounds have not been identified from the Verbenaceae. However, several bioactive compounds, including triterpenes have been identified in L. camara (Barre et al., 1997). Interestingly, L. camara is known to cause dermatitis in animals and it is believed that this reaction results from secondary photosensitization (Johnson \& Jensen, 1998), thus the term pseudophotophytodermatogen is used in describing the bioactivity of this species (J.C. Mitchell, personal communication). Both L. camara and the species of Phyllanthus (upon verification of the exact taxonomic status) are worthy of further investigation.

\section{Acknowledgments}

The authors thank Professor Emeritus M.D. Dassanayake and Ms. R.W. Edirisinghe of the National Herbarium, Peradeniya, Sri Lanka for assistance in plant identification; Staff, Sevangala Sugar Plantation, Sri Lanka for allowing access to sites and helping in the sampling; Department of Wildlife Conservation, Sri Lanka for permission to export plant material for the purpose of study by the first-named author, Zyta Abramowsky for advice and guidance in the laboratory, and Drs. Jon Page and Jeannette Whitton for useful comments and review of the manuscript.

\section{References}

Ali MS, Azhar I, Ahmad F, Ahmad VU, Usmanghani K (1999): Antimicrobial screening of some Papilionaceous (Fabaceous) plants. J Chem Soc Pak 21: 73-77.

Alves TMD, Silva AF, Brandao M, Grandi TSM, Smania EDA, Junior AS, Zani CL (2000): Biological screening of Brazilian medicinal plants. Mem Inst Oswaldo Cruz 95: 367-373.

Ashton MS, Gunatilleke S, de Zoysa N, Dassanayake MD, Gunatilleke N, Wijesundera S (1997): A Field Guide to the Common Trees and Shrubs of Sri Lanka. WHT Publications (Pvt.) Ltd., Sri Lanka. p. 432.

Bagchi GD, Singh A, Khanuja SPS, Bansal RP, Singh SC, Kumar S (1999): Wide spectrum antibacterial and antifungal activities in the seeds of some coprophilous plants of north Indian plains. J Ethnopharmacol 64: 69-77.

Baker AJM, Proctor J, Reeves RD (1992): The vegetation of ultramafic (serpentine) soils. Proceedings of the First International Conference on Serpentine Ecology. Intercept, Hampshire, UK. p. 509.

Barre JT, Bowden BF, Coll JC, Dejesus J, Delafuente VE, Janairo GC, Ragasa CY (1997): A bioactive triterpene from Lantana camara. Phytochemistry 45: 321-324.

Ben YS, Rodov V, Kim JJ, Carmeli S (1992): Preformed and induced antifungal materials of Citrus fruits in relation to the enhancement of decay resistance by heat and ultraviolet treatments. J Agric Food Chem 40: 1217-1221.

Berenbaum M (1995): Phototoxicity of plant secondary metabolites: Insect and mammalian perspectives. Arch Insect Biochem Physiol 29: 119-134.
Boyd RS, Shaw J, Martens SN (1994): Nickel hyperaccumulation defends Streptanthus polygaloides (Brassicaceae) against pathogens. Am J Bot 81: 294-300.

Boyd RS (1998): Hyperaccumulation as a plant defensive strategy. In: Brooks RR, ed., Plants that Hyperaccumulate Heavy Metals. CAB International, United Kingdom. pp. 181-201.

Broekaert WF, Cammue BPA, Debolle MFC, Thevissen K, Desamblanx GW, Osborn RW (1997): Antimicrobial peptides from plants. Crit Rev Plant Sci 16: 297-323.

Brooks RR (1987): Serpentine and its Vegetation. A Multidisciplinary Approach. Portland, OR, USA, Dioscorides Press. p. 454.

Bruneton J (1999): Pharmacognosy, Phytochemistry, Medicinal Plants. Second Edition. Lavoisier Publishing, France. p. 1119.

Camm EL, Towers GHN, Mitchell JC (1975): UV-mediated antibiotic activity of some Compositae species. Phytochemistry 14: 2007-2011.

Coleman RG, Jove C (1992): Geological origin of serpentinites. In: Baker AJM, Proctor J, Reeves RD, eds., The Vegetation of Ultramafic (Serpentine) Soils. Proceedings of the First International Conference on Serpentine Ecology. Intercept, Hampshire, UK. pp. 1-17.

Dahot MU (1999): Antibacterial and antifungal activity of small protein of Indigofera oblongifolia leaves. J Ethnopharmacol 64: 277-282.

Dash B (1991): Materia Medica of Ayurveda Based on Madanapala's Nighantu. B. Jain Publishers, New Delhi. p. 780.

Dassanayake MD, ed., (1980-2000): A Revised Handbook to the Flora of Ceylon. Volumes 1-14. A.A. Balkema, Rotterdam.

Devi P, Solimabi W, Dsouza L, Sonak S, Kamat SY, Singbal SYS (1997): Screening of some marine plants for activity against marine fouling bacteria. Bot Mar 40: 87-91.

Dubery IA, Louw AE, Van Heerden FR (1999): Synthesis and evaluation of 4-(3-methyl-2-butenoxy) isonitrosoacetophenone, a radiation-induced stress metabolite in Citrus. Phytochemistry 50: 983-989.

Ghaderian YSM, Lyon AJE, Baker AJM (2000): Seedling mortality of metal hyperaccumulator plants resulting from damping off by Pythium spp. New Phytol 146: 219-224.

Hanawa F, Tahara S, Mizutani J (1992): Antifungal stress compounds from Veratrum grandiflorum leaves treated with cupric chloride. Phytochemistry 31: 3005-3007.

Hanawa F, Tahara S, Towers GHN (2000): Antifungal nitro compounds from Skunk Cabbage (Lysichitum americanum) leaves treated with cupric chloride. Phytochemistry 53: 55-58.

Hashem FA, Sahab AF (1999): Chemical response of parsley and mentha herbs to certain stress agents. Food Chem 65 29-33.

Herrera RM, Perez M, Martinherrera DA, Lopezgarcia R, Rabanal RM, Arias A (1996): Antimicrobial activity of extracts from plants endemic to the Canary Islands. Phytother Res 10: 364-366.

Hudson JB, Towers GHN (1991): Therapeutic potential of plant photosensitizers. Pharmacol Ther 49: 181-222. 
Hungate BA, Jaeger CH, Gamara G, Chapin FS, Field CB (2000): Soil microbiota in two annual grasslands: Responses to elevated atmospheric $\mathrm{CO}_{2}$. Oecologia 124: 589-598.

Jayaweera DMA (1980-1982): Medicinal Plants (Indigenous and Exotic) Used in Ceylon. Volumes I-V. National Science Council of Sri Lanka. Colombo, Sri Lanka.

Johnson JH, Jensen JM (1998): Hepatotoxicity and secondary photosensitization in a red kangaroo (Megaleia rufus) due to ingestion of Lantana camara. J Zoo Wildl Med 29: 203-207.

Jovel EM, Cabanillas J, Towers GHN (1996): An ethnobotanical study of the traditional medicine of the Mestizo people of Suni Mirano, Loreto, Peru. J Ethnopharmacol 53: $149-156$.

Khafagi IK, Dewedar A (2000): The efficiency of random versus ethno-directed research in the evaluation of Sinai medicinal plants for bioactive compounds. J Ethnopharmacol 71: $365-376$.

Kruckeberg AR (1984): California Serpentines: Flora, Vegetation, Geology, Soils, and Management Problems. University of California Press. Berkeley, California. p. 180 .

Kruger BM, Manion PD (1994): Antifungal compounds in aspen: Effect of water stress. Can J Bot 72: 454-460.

Lennette EH (1985): Manual of Clinical Microbiology. Fourth Edition. American Association of Microbiology, Washington D.C. p. 1149.

Lewis WH, Elvin-Lewis MPF (1977): Medical Botany. Plants Affecting Man's Health. John Wiley \& Sons, New York. p. 515 .

McCutcheon AR, Ellis SM, Hancock REW, Towers GHN (1992): Antibiotic screening of medicinal plants of the British Columbian native peoples. J Ethnopharmacol 37: 213-223.

Mohamed F, Sehgal OP (1997): Characteristics of pathogenesisrelated proteins induced in Phaseolus vulgaris cv. Pinto following viral infection. J Phytopathol 145: 49-58.

Pal DC, Jain SK (1998): Tribal Medicine. Naya Prokash, Calcutta, India. p. 317.

Perez C, Suarez C (1997) Antifungal activity of plant extracts against Candida albicans. Am J Chinese Med 25: 181-184.

Pernas M, Sanchez-Monge R, Salcedo G (2000): Biotic and abiotic stress can induce cystatin expression in chestnut. FEBS Lett 467: 206-210.

Proctor J, Woodell SRJ (1975): The ecology of serpentine soils. Adv Ecol Res 9: 255-366.
Rajakaruna N, Bohm BA (2002): Serpentine and its vegetation: A preliminary study from Sri Lanka. J Appl Bot (in press).

Samy RP, Ignacimuthu S, Sen A (1998): Screening of 34 Indian medicinal plants for antibacterial properties. J Ethnopharmacol 62: 173-182.

Samy RP, Ignacimuthu S, Raja DP (1999): Preliminary screening of ethnomedicinal plants from India. J Ethnopharmacol 66: 235-240.

Samy RP, Ignacimuthu S (2000): Antibacterial activity of some folklore medicinal plants used by tribals in Western Ghats of India. J Ethnopharmacol 69: 63-71.

Sindambiwe JB, Calomme M, Cos P, Totte J, Pieters L, Vlietinck A, Vanden Berghe D (1999): Screening of seven selected Rwandan plants for antimicrobial and antiviral activities. J Ethnopharmacol 65: 71-77.

Sokmen A, Jones BM, Erturk M (1999): The in vitro antibacterial activity of Turkish medicinal plants. J Ethnopharmacol 67: 79-86.

Srinivasan D, Nathan S, Suresh T, Perumalsamy PL (2001): Antimicrobial activity of certain Indian medicinal plants used in folkloric medicine. J Ethnopharmacol 74: 217-220.

Tahara S, Kasai S, Inoue M, Kawabata J, Mizutani J (1994): Identification of mucondialdehyde as a novel stress metabolite. Experientia 50: 137-141.

Taylor RSL, Edel F, Manandhar NP, Towers GHN (1996): Antimicrobial activities of southern Nepalese medicinal plants. J Ethnopharmacol 50: 97-102.

Towers GHN (1984): Interactions of light with phytochemicals in some natural and novel systems. Can $J$ Bot 62: 2900-2911.

Towers GHN, Page JE, Hudson JB (1997): Light-mediated biological activities of natural products from plants and fungi. Curr Org Chem 1: 395-414.

Valsaraj R, Pushpangadan P, Smitt UW, Adersen A, Nyman U (1997): Antimicrobial screening of selected medicinal plants from India. J Ethnopharmacol 58: 75-83.

Vigers AJ, Roberts WK, Selitrennikoff CP (1991): A new family of plant antifungal proteins. Mol Plant-Microbe Interact 4: $315-323$.

Weiersbye IM, Przybylowicz WJ (1999): Accumulation of metals during plant hypersensitive disease resistance to microbes is associated with reduced parasitic fitness. In: Conference Program and Abstracts, Third International Conference on Serpentine Ecology, Kruger National Park, South Africa, and Proctor, J (1999): Toxins, nutrient shortages and droughts: The serpentine challenge. Trends Ecol Evol 14: 334-335. 